\section{Helping Canadians Understand the Opportunities for Health Research}

Patrick Rafferty

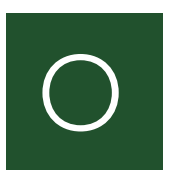

ver the last hundred years, new knowledge in health has contributed more to economic prosperity and living standards than investments in all other technologies and sectors combined (William D. Nordhaus, Yale University). Improvements in life expectancy have moved independently of growth in GNP, and historical gains from increased longevity in the USA from 1970 to 1990 annually exceeded $\$ 2.8$ trillion (Levon M. Murphy and Robert Topel, University of Chicago). Increases in total R\&D spending of $2 \%$ per year would increase economic output by $0.5 \%$ per year, increasing GDP by $28 \%$ by 2050 - enough to resolve all budget difficulties associated with the aging baby boom generation and still leave ample resources for dealing with other pressing social problems (Paul M. Romer, Stanford University). Hospitalization and home care savings from new drugs are seven times greater than the costs of new drugs (Frank Lichtenberg, Columbia University). These may be some of the reasons why American health R\&D investments now exceed US\$94 billion per year (Alerion Institute): $57 \%$ by industry; $28 \%$ by the federal National Institutes of Health; and $15 \%$ by foundations, state governments and others.

To be on a level playing field with the USA, prorated to population, Canada would need to more than double its annual investment in health research to about $\$ 12$ billion: about $\$ 7$ billion by industry; about $\$ 3.4$ billion by the federal government; and about $\$ 1.8$ billion by provinces, universities and foundations. Actual investments for 2004 were only $\$ 5.7$ billion: $\$ 1.6$ billion by industry; $\$ 1.1$ billion by the federal government; $\$ 1.7$ billion by provinces, universities and foundations; and $\$ 0.7$ billion from foreign sources (Statistics Canada Catalogue 88-001-XIE/ISSN1209-1278).

Industry and federal investments suffer because policy leadership falls between health, industry, science, education, environment, agri-food and finance ministries, and between social and economic cabinet committees. From bottom to top, conflicting bureaucracies, constituencies, and values invite inertia, if not overt resistance, to progressive policies. Small-c "conservatism" can be more rewarding than "innovation." The net result is that we do not have one minister, federal or provincial, or one legislative committee that has made a serious effort to reach out to the interested parties and understand and articulate the opportunities and risks at stake for Canada. Even Mr. Romanow's Royal Commission was virtually silent on the role of health research. At a time when global leaders are rationalizing about
\$200 billion of global R\&D efforts to focus on only the most promising programs, we are being left behind by jurisdictions with clusters of 20,000 to 40,000 researchers and more cohesive strategies such as Massachusetts, California, Texas, Pennsylvania, UK, Singapore, Finland, Sweden, Ireland and France.

Prior to becoming Prime Minister, Mr. Martin gave encouraging speeches on the topic. Moving ideas forward must have proved to be too difficult without broader public understanding or support. Mr. Harper and a Conservative government's readiness or willingness to take on the responsibility of providing leadership to the health research sector is unknown.

Canada represents about $3 \%$ of the world demand for health goods and services and about $1.5 \%$ of the supply. By comparison, the UK represents about $6 \%$ of the demand and about $12 \%$ of the supply. Achieving a ratio similar to the UK ratio would generate a trade surplus of more than $\$ 10$ billion and an industry of more than 100,000 knowledge-intensive jobs.

Instead, Canada has a trade deficit of about $\$ 10$ billion in health goods and services. This deficit is of the same order of magnitude as our surpluses in energy, agri-food, automobiles or forest products. Are we clearcutting our forests to finance our drug habit?

The federal government deserves credit for tripling its investments in the last 10 years, including the creation of the Canadian Institutes for Health Research, Genome Canada, Canada Foundation for Innovation, Canada Health Infoway, Canada Research Chairs, Canadian Health Services Research Foundation, as well as its investments in National Science and Engineering Research Council, Social Science and Humanities Research Council and the National Research Council. Capacity has improved tremendously. We have many outstanding scientists, by measures such as citations in the world literature, and a new level of willingness among scientists to network and cooperate across disciplines and institutional boundaries.

However, only the most risk-tolerant investor, such as labour-sponsored venture capital funds, would even think about actually investing in developing new health discoveries in Canada. Why?

We still have huge weaknesses in our innovation system to be corrected:

- We are slow at getting the world's best science knowledge and therapies into clinical practice. For example, cancer experts suggest that $50 \%$ of all cancer deaths $(68,000$ per year) could be avoided if we could use the diagnostic and therapeutic knowledge and technologies now available. Moving from early discovery to pre-clinical research in animal models, Phase 1, 2 and 3 clinical trial networks, ethics review boards, and links to patient records are not well enough developed to make Canada an attractive place to translate discoveries into clinical therapies and products. The leadership role that can 
be played by Canada's relatively new regional health authorities has no dedicated funding for that purpose. Thousands of promising diagnostics and therapies across all disease categories are not available to Canadians, while our regulators replicate the work of others. Our regulatory approach could offer value unique in the world by migrating to large-scale disease management studies and Phase 4 monitoring studies of the impact of alternative treatments on large populations. Patients in trials have statistically better outcomes even if they are given conventional treatments or placebos, and trial sponsors will tend to pay for the majority of the costs of care. While provinces focus on basic affordable healthcare, the federal government is well positioned to identify and support the implementation of best practices in disease prevention, diagnostics, care and rehabilitation. Mental health, cancer, diabetes and stroke - diseases that will affect the majority of the population - are examples of fields where Canada could, within five years, become the international "Blue seal of approval" in terms of best-practice knowledge.

- Human resources and careers in health research are poorly managed. Academic, clinical and industry needs are not anticipated. We are underfunding our outstanding scientists. Internationally competitive professors with efficient teams should be working with a budget of \$2-4 million per year: about 10 times what the majority of full professors are operating with in Canada. There are too many competitions for too few resources, compounded by compelling needs to finance salaries that ministries of education and health are not willing to finance. Tenure, decision-making for academic positions, grant competitions and term limits to grants create great differences in organizational cultures, career risks and barriers to seamless academic, clinical and industry transitions. Over 15 years, intense competition has reduced a $\mathrm{PhD} /$ MD clinical researcher 50/50 balance to a ratio of less than $85 / 15$. Far more clinical researchers are needed to link developments in science with patients and the healthcare system.

- Tax policies prohibit sensible investments in health research. Incentives are only available to profitable companies whose primary business is health. Incentives are not available to all the owners, managers and risk-tolerant and innovative investors needed to take new discoveries through each stage of the 10-to -15-year development life cycle. The type of "flow through" and "limited partnership" incentives available to the Canadian oil and gas exploration and development for 30 years, and comparable to what the US offers for health innovation expenditures, would attract managerial talent and hundreds of millions of high-risk dollars into health innovation. Without these transitional owners and investors, there are too many scientific opportunities and too little infrastructure to bring these discoveries to the point that justifies industry investment.
- Canadian executives of multinationals have great difficulty competing to attract investments into Canada in competition with 40 or more research-competent jurisdictions. Most multinationals are almost desperate to focus on a short list, less than 10, of the most promising centres, partnerships or programs. Finding new products for their distribution systems is essential for their survival, and many are only surviving by merger. Canada is barely on the radar screen. Few multinationals have given their Canadian operations a world product research mandate. We need to adopt a "Team Canada" approach to ensure that Canada is providing the best possible private and public resources and programs to support important research mandates for Canadian subsidiaries. Our research focus has to be strong enough to overcome the irritant that for about 15 years, most provinces have refused to pay drug prices determined to be "fair" by the federal Pharmaceutical Prices Review Board.

- Canada's pension and mutual fund portfolios, valued at something in the order of $\$ 2$ trillion, are generally not attracted to the Canadian life sciences sector. Public policies have focused on allowing them to increase foreign investments. If policies encouraged even $1 \%$ of our pensions to be invested domestically in this science of the future, it would represent a truly transformative $\$ 20$ billion. This is unlikely to happen until Canadian scientists learn to pool their efforts into large internationally competitive programs, partnered with the best in the world, led by the best managers in the world, ready to protect, buy and defend large pools of intellectual property, and ready to spread risks over many opportunities.

A business case could likely be made for investing hundreds of millions of dollars in remedying each of these weaknesses. However, remedying any one of these weaknesses by itself is likely to lead to disappointment. Dealing with all of these weaknesses in an orderly, integrated and practical way is relatively simple if the political prejudices and biases can be overcome, and the right people can be drawn into the decision-making and governance structures.

Let us hope that at least one member of the new Parliament, or even better, a small nucleus of three or four, will take it on themselves to understand and try to provide some sustained public policy leadership for the health research sector.

\section{About the Author}

Patrick Lafferty, FCA, CMC is a retired partner of

PricewaterhouseCoopers LLP who has advised the life sciences sector across Canada for many years and is a member of the Boards of Friends for Canadian Institutes of Health Research and the University of Ottawa Institute of Mental Health Research. 